\title{
Population Genetics of Tor douronensis in Sarawak - A Revisit
}

\author{
MUHAMMAD AMIRUL ARIB MD ADZHAR* \& RUHANA HASSAN \\ Department of Aquatic Science, Faculty of Resource Science and Technology, Universiti Malaysia \\ Sarawak, 94300 Kota Samarahan, Malaysia
}

\begin{abstract}
Tor douronensis, known locally as Semah, is one of the valuable resources of Sarawak due to its high nutritional value and demand as game fish. Several molecular studies related to $T$. douronensis have been carried out and deposited in GenBank including the data collected from Ba Kelalan, Layar and Limbang. Although there are other studies on Tor spp., the data was not available in GenBank, thus there are not included in the analysis. One fieldtrip to Bakun Dam was carried out on June 2014 with initial aim to assess overall fish diversity. During this sampling, 11 individuals of $T$. douronensis were caught, which later subjected to molecular work to investigate the genetic structure and evolutionary relationship among four of $T$. douronensis in Sarawak using partial Cytochrome c oxidase I (COI) mtDNA gene. A fragment of $465 \mathrm{bp}$ of CO1 gene of T. douronensis was successfully amplified. Based on the phylogenetic trees generated, three clades could be observed namely Central, Southern, and Northern populations; $1^{\text {st }}$ clade (haplogroup I) from Bakun, $2^{\text {nd }}$ clade (haplogroup II) from Layar and $3^{\text {rd }}$ clade (haplogroup III) from Ba Kelalan and Ulu Limbang. Overall, there were 13 haplotypes and none was shared among populations, suggesting low level of inter-population gene flow has been observed. The small number of migrants per generation $(\mathrm{Nm}<1.0)$ among the population indicated that the small populations were isolated possibly due to large geographical areas. All population had undergone expansion with a large negative value and significant test of Fu's F in Bakun population suggested recent expansion. In addition, result also suggested that all populations did not deviate from evolutionary neutrality.
\end{abstract}

Keywords: COI gene, evolutionary neutrality, population expansion, population subdivision, Tor douronensis

\section{INTRODUCTION}

Tor douronensis Valenciennes (1842) is a member of the mahseer group from the genus Tor Gray in the family Cyprinidae. It is one of the most important freshwater fishes in Malaysia (Mohsin \& Ambak 1983; Roberts 1989; Litis et al., 1997; Ng, 2004) inhabiting the upper streams and headwaters of most major river systems (Kottelat et al., 1993; Rainboth, 1996). In Sarawak, T. douronensis is locally known as Semah. This species has high economic value to the local people.

About a decade ago, the price of $T$. douronensis was valued RM45/kg in the open market in Kapit, Sarawak (Ingram et al., 2005). During field visit to Bakun Dam in April 2013, local people claimed that 'Semah' could fetch a price of between RM60/kg to RM100/ $\mathrm{kg}$ in Bakun area. Thus in agreement with Ingram et al. (2005), this species has great potential for freshwater aquaculture industry.

Populations of Tor spp. are declining due to degrading environmental conditions by deforestation, logging and development of hydropower dam that may have disturbed their natural habitat $(\mathrm{Ng}, 2004)$. Uncontrolled fish harvest (overfishing) due to its high price has also contributed to the reduction of their population size (Ng, 2004). Their distributions in Malaysian Borneo are now limited to the upper streams and protected areas of Sarawak and Sabah (Litis et al., 1997; Nyanti et al., 1999; $\mathrm{Ng}, 2004)$.

Although currently not listed by the IUCN as a protected or endangered species, the drastic decline in natural populations of $T$. douronensis has increased awareness among relevant authorities (e.g., Fisheries Department, 
Malaysia and policy makers) of the importance of the conservation and proper management of this species (Esa et al., 2008). Due to its economic importance, high commercial, recreational and conservational value, $T$. douronensis needs a proper management plan to ensure its sustainability. It is crucial to understand their taxanomic status, population distribution, genetic variability, levels of gene flow and population subdivisions and for understanding factors contributing to fitness of $T$. douronensis. This would ensure a more effective management plan could be developed with the aim for long-term maintenance of genetic diversity of cultured stocks, as well as to minimize potential adverse effects on the genetic integrity of the wild populations through proper stock enhancement practices.

Esa et al. (2008) had carried out genetic studies on $T$. douronensis involving Layar, $\mathrm{Ba}$ Kelalan and Ulu Limbang populations. However, he suggested that larger sample sizes per population and samples from other areas are required to reveal the actual genetic variation at the inter-population and intra-populations levels. In this current study, a re-analysis of the previous study was conducted with the addition of the Bakun Dam population.

Thus, the aim of this study is to conduct a population genetic study among four populations from Sarawak using partial DNA sequence of the Cytochrome c Oxidase I (COI) mtDNA gene analysis.

\section{MATERIALS AND METHODS}

\section{Collection of Samples}

Eleven $T$. douronenis samples were obtained from Bakun Dam (N 02 $45^{\prime} 23^{\prime \prime}$, E $114^{\circ} 03^{\prime} 47^{\prime \prime}$ ) (Figure 1). Other data were obtained from Genbank with accession number, EF192444, EF192445 (Ulu Limbang samples), EF192453, EF192454, EF192455, EF192456 (Layar samples) and EF192446, EF192447 (Ba Kelalan samples.

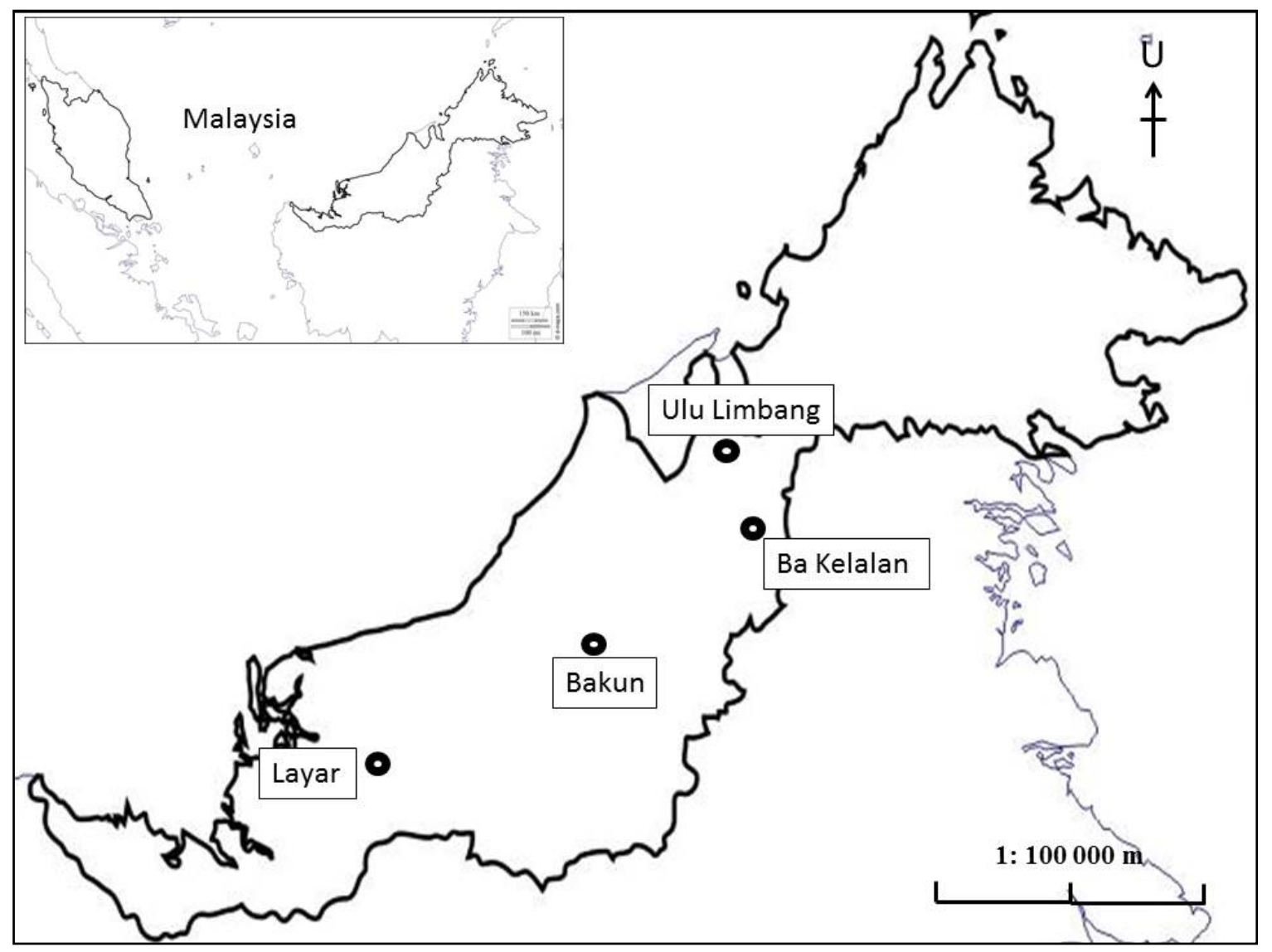

Figure 1. Location of T. douronensis populations involved in this study (Source: Google Map). 
All samples were collected using cast nets or pole nets. The muscle tissues from each sample were collected and preserved in 95\% ethanol and later transported back to Aquatic Molecular Laboratory, Faculty of Resource Science and Technology, UNIMAS for further analyses. The samples were identified using keys provided by Mohsin \& Ambak (1983), Kottelat et al. (1993) and Inger \& Chin (2002).

\section{DNA Extraction and Polymerase Chain Reaction (PCR) and Sequencing}

Total genomic DNA of each sample was extracted using the modified Cetyl-trimethyl Ammonium Bromide (CTAB) method (Doyle \& Dickson, 1987) with the addition of proteinase K. The amplification of COI gene fragment was conducted using oligonucleotide primers COIf (5'-CCT GCA GGA GGA GGA GAY CC-3', forward) and COIe (5'-CCA GAG ATT AGA GGG AAT CAG TG-3', reverse) (Palumbi et al., 1991). PCR for COI mtDNA gene was carried out following Esa et al. (2008) in a programmable gradient-enabled thermocycler (Bio-Rad MyCycler ${ }^{\mathrm{TM}}$ Thermal Cycler). Approximately, 50-100 ng of the template DNA was amplified in a $25 \mu \mathrm{L}$ reaction mixture containing $50 \mathrm{mM} 10 \mathrm{x}$ buffer, $2 \mathrm{mM} \mathrm{MgCl}, 0.4 \mathrm{mM}$ of dNTPs (Promega), 0.2 $\mathrm{mM}$ of each primer, and $0.5 \mathrm{U}$ of Taq DNA polymerase (Promega). The cycle parameters included pre denaturation step at $95^{\circ} \mathrm{C}$ for $5 \mathrm{~min}$, followed by 35 cycles of denaturation at $95^{\circ} \mathrm{C}$ for $30 \mathrm{~s}$, annealing at $47^{\circ} \mathrm{C}$ for $30 \mathrm{~s}$, and extension at $72^{\circ} \mathrm{C}$ for $60 \mathrm{~s}$ with final extension step at $72^{\circ} \mathrm{C}$ for $5 \mathrm{~min}$ followed by $1 \%$ agarose gel electrophoresis. Reverse and forward sequencing were conducted by First Base Laboratories Sdn Bhd, Kuala Lumpur.

The procedures to align the sequences, obtain comparative data to construct the phylogenetic tree, and assign a degree of confidence to the trees was followed from Matsui et al. (2005). The sequence was aligned with Clustal X (Thompson et al., 1997) and translated to amino acid sequences in MEGA 4.1 (Kumar et al., 2008).

Maximum-likelihood (ML) and Bayesian analyses were based on the substitution model and phylogenetic parameters $(\mathrm{HKY}+\mathrm{G})$ identified as optimal by the Bayesian information criterion (BIC) in jModeltest (Posada, 2008). The confidence levels of the maximum-parsimony (MP) and ML analyses were analysed using PAUP4.0b10 (Swofford, 2000 ). Only bootstrap values of $\geq 70 \%$ was regarded as sufficiently resolved topologies (Huelsenbeck \& Hillis, 1993) and those of 50\%$70 \%$ as tendencies. For the Bayesian analysis using MrBayes (Huelsenbeck \& Ronquist, 2001), the same substitution model as used for the ML analysis was used with two simultaneous metropolis-coupled Monte-Carlo Markov chains that was run for 106,000 generations or until the probability of split frequencies, $p<0.01$. A tree was sampled every 100 generations, and a consensus topology was calculated for 795 tree by omitting the first 265 trees (as burn-in). The confidence level of tree nodes was indicated by posterior probabilities which represent the true probabilities of the clades (Rannala \& Yang, 1996). Posterior probabilities of $\geq 98 \%$ was considered significant (Leache \& Reeder, 2002).

The measurement of population genetic parameters such as genetic diversity (the probability that two randomly chosen mtDNA sequences differed in the sample) and nucleotide diversity (per nucleotide site, i.e., the probability that two randomly chosen homologous nucleotides differ in the sample (Nei, 1987) was estimated from the mtDNA dataset using DNASP 4.0 (Rozas et al., 2003). Estimates of nucleotide divergence among populations, after accounting for nucleotide diversity within populations (Da), were also generated using DNASP 4.0.

The demographic history was examined by Tajima's test of neutrality, D (Tajima, 1989), and the deviation of sequence variation from evolutionary neutrality was tested using Fu's Fs statistics test $(\mathrm{Fu}, 1997)$. A population that has experienced population expansion may result in rejection of the null hypothesis of neutrality of Tajima's D, or a large negative value of Fu's Fs. All analyses were computed in Arlequin vers. 3.00 (Excoffier et al., 2005).

The extent of population differentiation investigation was conducted by dividing the individual into broad geographical groups, based on the ML topology of the mtDNA phylogeny. These groupings were compared by 
analysis of molecular variance (AMOVA, Excofficer et al., 2005).

The population expansion events were performed using a mismatch distribution analysis (Roger \& Harpending, 1992; Rogers, 1995) using Arlequin vers. 3.0 with 1000 permutations (Excofficer et al., 2005) and sitefrequency spectra (Donnelly et al., 2001) as implemented in DNaSP 4.0 (Rozas et al. 2003). The parsimony criterion was used to construct haplotype relationships of $T$. douronensis, assuming that differences at any given site between two randomly drawn haplotypes was unlikely to have arisen from more than one mutational step (Alexandrino et al., 2002). In addition, a minimum-spanning network (MSN) was generated using Network 4.5.0.2 (Bandelt et al., 1999) to illustrate these relationships.

\section{RESULTS AND DISCUSSION}

A total $465 \mathrm{bp}$ of $\mathrm{CO} 1$ gene of T. douronensis was successfully amplified using CO1 gene primers. The overall frequency distributions of nucleotides at the $1^{\text {st }}, 2^{\text {nd }}$ and $3^{\text {rd }}$ codon position were as follows: $\mathrm{T}=29.0 \%, \mathrm{C}=19.5 \%$, $\mathrm{A}=34.0 \%$, and $\mathrm{G}=17.7 \%$; $\mathrm{T}=30.0, \mathrm{C}=25.4 \%$, $\mathrm{A}=23.3 \%$, and $\mathrm{G}=20.9 \% ; \mathrm{T}=38.0 \%, \mathrm{C}=23.9 \%$, $\mathrm{A}=20.3 \%$, and $\mathrm{G}=18.3 \%$, respectively. $\mathrm{A}$ compositional nucleotide bias analysis revealed no significant bias $(\mathrm{p}=1.29)$ across the $T$. douronensis populations. There were 23 $(4.9 \%)$ variables sites with seven singletons, leaving $16(69.6 \%)$ potentially parsimoniously informative characters, indicating that the gene is a reliable marker to infer genetic variations at the population level and $442(95.1 \%)$ site were conserved. Within the dataset, transition occurred more than transversion, in agreement with Briolay et al. (1998).

The genetic distance among $\mathrm{CO} 1$ sequence of $T$. douronensis ranged from $0.0 \%$ to $0.9 \%$ (intra-population) and $0.0 \%$ to $3.6 \%$ (interpopulation) indicating high disparities in differentiation in intra-population and interpopulation (Table 1). According to Nguyen et al. (2006), high inter-population genetic distance could be explained by several factors including small population size, past bottleneck event and physical barriers among populations. In addition, Palumbi (1994) claimed that genetic variation and structure may also increase due to geographical distance. Hence, a population genetic analysis was conducted to further understand the genetic structure of $T$. douronensis from Sarawak.

Among the 11 individuals sequenced and eight GenBank sequences (EF192453, EF192454, EF192455, EF192446, EF192447, EF192444, EF192445), 13 haplotypes were identified with no haplotype shared among them (Table 2). Bakun population consisted of five haplotypes from 11 individuals, none of which was shared with the other three populations (Table 3).

Moreover, low intra population nucleotide diversity $(\pi)$ was observed ranging from $0.04 \%$ to $0.12 \%$ (Table 3 ). Low inter population nucleotide diversity $(\pi)$ were recorded ranging $0.3 \%$ to $1.7 \%$ and between $0.00 \%$ to $2.72 \%$ in net nucleotides divergence (DA) (Table 4). The $\mathrm{Da}$ (Table 4) values were high when comparing Ba Kelalan with Bakun (2.72\%) than Ba Kelalan with Layar (2.29\%) even though both sites are separated by $470 \mathrm{~km}$. A lack of differentiation (zero value of net nucleotide divergence) (Table 5) can be observed between Ulu Limbang and and Ba Kelalan which are separated about $98 \mathrm{~km}$ from each other. Similarly, Esa et al. (2006) reported population of $T$. douronensis of Peninsular Malaysia was particularly closer to Sarawak population compared to Sabah population although Peninsular and Sarawak are separated by longer distance due to geographical isolation of interconnected river. Thus, this study also suggested that geographical distance between populations is very unlikely to influence the net nucleotide divergence.

Phylogenetic analyses of $T$. douronensis from Sarawak produced similar tree topologies for Maximum Parsimony (MP) (Figure 2), Neighbour-joining (NJ) (not shown), Bayesian Inferences (BI) (Figure 3) and Maximum likelihood (ML) (not shown). They revealed a monophyly of $T$. douronensis from Sarawak with respect to outgroups Neolssochilus stracheyi and Hampala dispar with bootstrap value of $98 \%$ (MP), 99\% (NJ), 100\% (ML) and 1.0 Bayesin posterior probability of (BPP) in BI. Similarly, Esa et al. (2006) and Esa et al. (2008) also reported T. douronensis is monophyletic. 
Table 1. Summary of genetic distance in percentage (\%) within and among populations for CO1 gene sequences of T. douronensis.

\begin{tabular}{lcccc}
\hline & Bakun & Layar & Ba Kelalan & Ulu Limbang \\
\hline Bakun & $0.0-0.7$ & - & & \\
Layar & $1.1-2.7$ & $0.4-0.9$ & - & \\
Ba Kelalan & $2.9-3.6$ & $2.7-3.1$ & $0.0-0.4$ & - \\
Ulu Limbang & $2.7-3.4$ & $2.2-3.1$ & $0.2-0.4$ & $0.0-0.2$ \\
\hline
\end{tabular}

The phylogenetic tree re-construction based on CO1 gene variation also reveals that the $T$. douronensis is divided into three geographical clades. Clade I is comprises all T. douronensis from Bakun with, $84 \%, 86 \%, 83 \%, 0.57$ for MP, NJ, ML and BI respectively. Clade II consists of population from Layar $(86 \%, 74 \%$, $100 \%, 0.63)$. and clade III consists of $\mathrm{Ba}$ Kelalan and Ulu Limbang population are well resolved with high bootstrap values (98\%, $99 \%, 100 \%, 0.93)$. Both clade I and II are considered as sufficiently resolved (Huelsenbeck \& Hillis, 1993) as the bootstrap values more than $70 \%$.

From the network analysis (Figure 4), minimum-spanning network (MSN) model showed that there were three haplogroups among the population. Haplogroup I is consisted of Bakun population, haplogroup II consist of Layar samples and haplogroup III consist of Ba Kelalan and Limbang population with no sharing of haplotype although Layar and Bakun population were interconnected. Missing haplotypes (mv) can be observed in Figure 4, suggesting future work needs to involve more samples in the analysis and suggested the network was not fully resolved. The MSN result is consistent with the topologies of all trees (Figure $2 \& 3$ ).

The scatterplot of the mismatch distributions analysis in Bakun population illustrates a unimodal interpretation of the mismatch distribution, while $T$. douronensis population from Layar illustrate multimodal interpretation (Figure 5). A unimodal distribution is indicative of population expansion. Thus this suggest that the Bakun population passed through a recent demographic expansion (Rogers \& Harpending, 1992; Hudson \& Slatkin, 1991) or a range expansion with high level of migration between neighbouring demes (Ray et al. 2003; Excoffier, 2004). On the other hand, a multimodal distribution shows that populations are at demographic equilibrium (Rogers \& Harpending, 1992) and reflects a highly stochastic shape of the evolutionary lineages as observed in Layar. In this study, mismatch distribution scatterplots for Ulu Limbang and Ba Kelalan populations could not be illustrated due to the small variance of the mismatch distribution thus no demographic parameters could be estimated for these two populations.

Furthermore, mismatch distribution of pairwise nucleotide differences among $\mathrm{CO} 1$ gene sequences in Bakun population showed small SSD value is 0.007 , which is lack of significance value $(\mathrm{p}=0.652)$ (Table 6) suggesting population expansion hypotheses following the expected distribution under a sudden expansion model (Rogers \& Harpending, 1992; Hudson \& Slatkin, 1991). However, higher SSD with significance value $(\mathrm{SSD}=0.297, \mathrm{p}=0.04)$ showed that the Layar population has no recent sudden expansion and the population are at demographic equilibrium (Rogers \& Harpending, 1992). Small values of Harpending's raggedness index from Bakun population $(\mathrm{r}=0.099)$ with lack of significance $(p=0.626)$, as shown on Table 6 , revealed unimodal interpretation of the mismatch distribution in T. douronensis. In contrast, small Harpending's raggedness index in the Layar 
Table 2. Samples of $T$. douronensis $(T . d)$ analysed for (CO1) gene sequence variation with locality, GPS reading, field voucher and identified haplotype.

\begin{tabular}{|c|c|c|c|c|}
\hline Species & Haplotype & Locality & GPS reading & $\begin{array}{c}\text { Field Voucher/ } \\
\text { GenBank }\end{array}$ \\
\hline T. $d$ & Hap_1 & Bakun, Sarawak & N0245'23",E11403'47" & BK01 \\
\hline T. $d$ & Hap_3 & Bakun, Sarawak & N0245'23",E11403'47" & BK02 \\
\hline T. $d$ & Hap_1 & Bakun, Sarawak & N02 $45^{\prime} 23^{\prime \prime}, \mathrm{E} 114^{\circ} 03^{\prime} 47^{\prime \prime}$ & BK03 \\
\hline T. $d$ & Hap_1 & Bakun, Sarawak & N02 $45^{\prime} 23^{\prime \prime}, \mathrm{E} 114^{\circ} 03^{\prime} 47^{\prime \prime}$ & BK04 \\
\hline T. $d$ & Hap_1 & Bakun, Sarawak & N02 $45^{\prime} 23^{\prime \prime}, \mathrm{E} 114^{\circ} 03^{\prime} 47^{\prime \prime}$ & BK05 \\
\hline T. $d$ & Hap_2 & Bakun, Sarawak & N02 $45^{\prime} 23^{\prime \prime}, \mathrm{E} 114^{\circ} 03^{\prime} 47^{\prime \prime}$ & BK06 \\
\hline T. $d$ & Hap_4 & Bakun, Sarawak & N0245'23",E11403'47" & BK07 \\
\hline T. $d$ & Hap_2 & Bakun, Sarawak & N02 $45^{\prime} 23^{\prime \prime}, \mathrm{E} 114^{\circ} 03^{\prime} 47^{\prime \prime}$ & BK08 \\
\hline T. $d$ & Hap_1 & Bakun, Sarawak & N02 $45^{\prime} 23^{\prime \prime}, \mathrm{E} 114^{\circ} 03^{\prime} 47^{\prime \prime}$ & BK09 \\
\hline T. $d$ & Hap_1 & Bakun, Sarawak & N02 $45^{\prime} 23^{\prime \prime}, \mathrm{E} 114^{\circ} 03^{\prime} 47^{\prime \prime}$ & BK10 \\
\hline T. $d$ & Hap_5 & Bakun, Sarawak & N02 $45^{\prime} 23^{\prime \prime}, \mathrm{E} 114^{\circ} 03^{\prime} 47^{\prime \prime}$ & BK11 \\
\hline T. $d$ & Hap_6 & Layar, Sarawak & NA & $\begin{array}{c}\text { EF192454 } \\
\text { (LA01) }\end{array}$ \\
\hline T. $d$ & Hap_9 & Layar, Sarawak & NA & $\begin{array}{c}\text { EF192454 } \\
\text { (LA02) }\end{array}$ \\
\hline T. $d$ & Hap_12 & Layar, Sarawak & NA & $\begin{array}{c}\text { EF192455 } \\
\text { (LA03) }\end{array}$ \\
\hline T. $d$ & Hap_13 & Layar, Sarawak & NA & $\begin{array}{c}\text { EF192456 } \\
\text { (LA04) }\end{array}$ \\
\hline T. $d$ & Hap_7 & Ba Kelalan, Sarawak & NA & $\begin{array}{c}\text { EF192446 } \\
\text { (BA01) }\end{array}$ \\
\hline T. $d$ & Hap_8 & Ba Kelalan, Sarawak & NA & $\begin{array}{c}\text { EF192447 } \\
\text { (BA02) }\end{array}$ \\
\hline T. $d$ & Hap_10 & Ulu Limbang, Sarawak & NA & $\begin{array}{c}\text { EF192444 } \\
\text { (LI01) }\end{array}$ \\
\hline T. $d$ & Hap_11 & Ulu Limbang, Sarawak & NA & $\begin{array}{l}\text { EF192445 } \\
\quad(\text { LI02) }\end{array}$ \\
\hline
\end{tabular}


Table 3. Segregating sites ( $23 \mathrm{bp}$ ) in the $465 \mathrm{bp}$ of $\mathrm{CO} 1$ gene of $T$. douronensis.

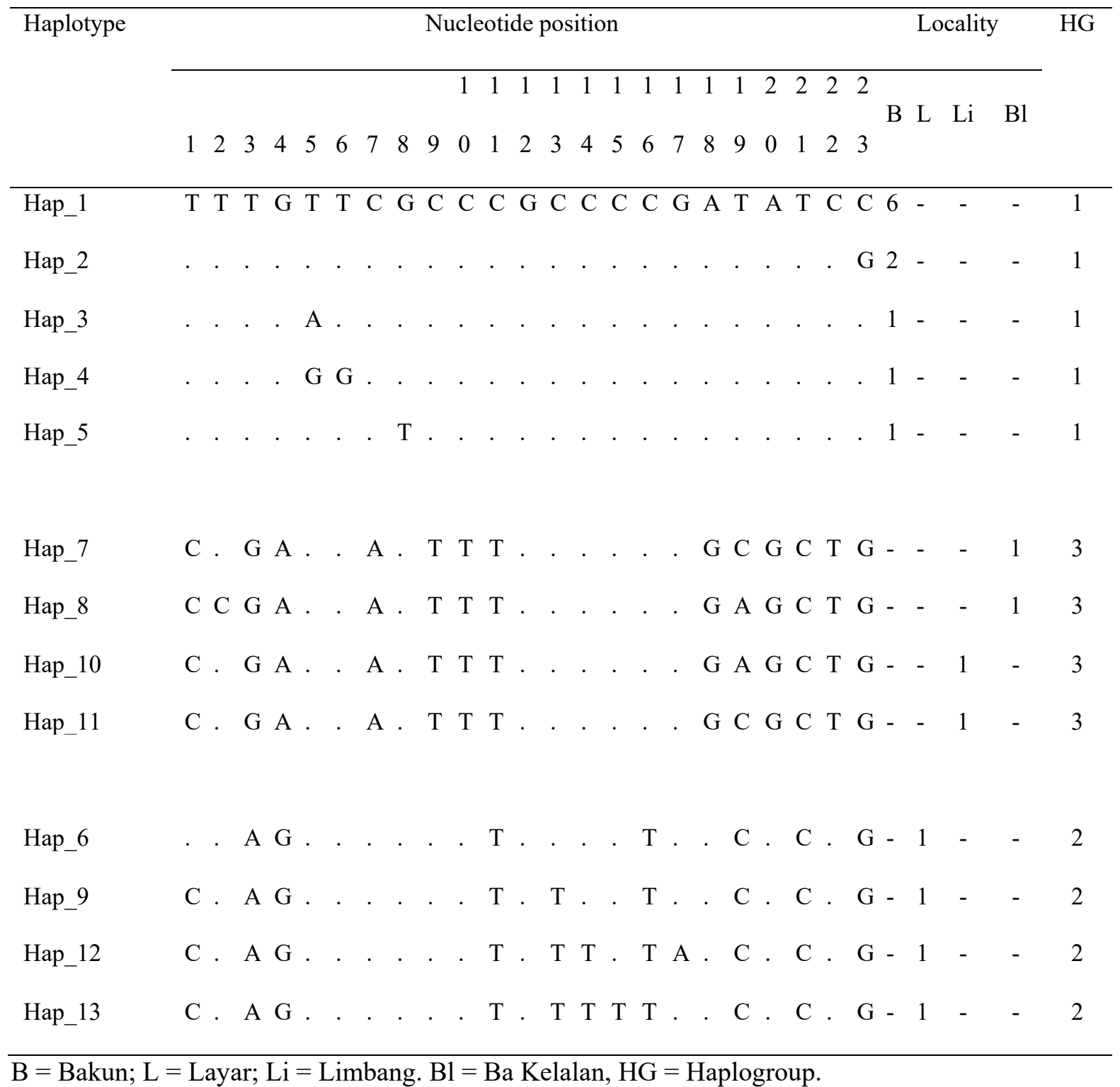

Table 4. Measures of haplotype and nucleotide diversity within populations of T. douronensis analysed by location.

\begin{tabular}{lcccc}
\hline Locality & $\mathrm{H}$ & Percent (\%) pairwise divergence & Gene diversity & Nucleotide diversity \\
\hline Bakun & 5 & $0.0-0.7$ & $0.0071 \pm 0.0013$ & $0.0005 \pm 0.03$ \\
Layar & 4 & $0.4-0.9$ & $0.0010 \pm 0.0018$ & $0.0012 \pm 0.09$ \\
Ba Kelalan & 2 & 0.4 & $0.0010 \pm 0.0050$ & $0.0008 \pm 0.11$ \\
Ulu Limbang & 2 & 0.2 & $0.0010 \pm 0.0050$ & $0.0004 \pm 0.06$ \\
\hline
\end{tabular}

$\mathrm{H}=$ number of haplotypes. 
Table 5. Measures of nucleotide diversity $(\pi)$ and net nucleotide divergence (Da) among populations of $T$. douronensis analysed by location.

\begin{tabular}{lccc}
\hline Locality & Distance $(\mathrm{km})$ & $\begin{array}{c}\text { Nucleotide diversity } \\
(\pi)\end{array}$ & $\begin{array}{c}\text { Net Nucleotide } \\
\text { divergence (Da) }\end{array}$ \\
\hline Bakun-Layar & 248 & 0.0093 & 0.0141 \\
Bakun-Ulu Limbang & 280 & 0.0096 & 0.0262 \\
Bakun-Ba kelalan & 215 & 0.0102 & 0.0272 \\
Layar-Ulu Limbang & 540 & 0.0156 & 0.0208 \\
Layar-Ba kelalan & 470 & 0.0175 & 0.0229 \\
Ulu Limbang-Ba kelalan & 98 & 0.0032 & 0.0000 \\
\hline
\end{tabular}

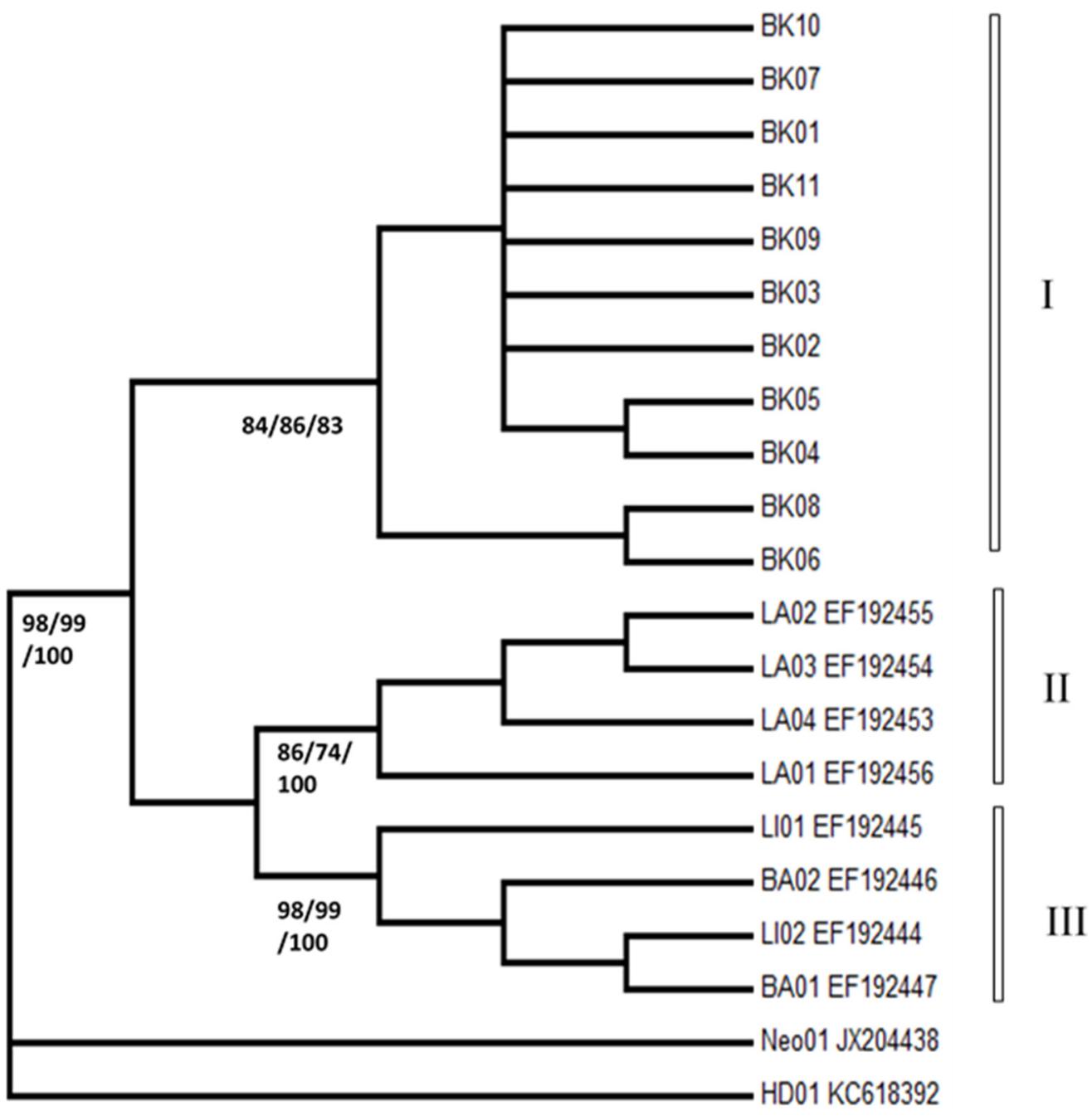

Figure 2. A maximum parsimony 50\% majority rule consensus tree constructed of CO1 gene sequence of $T$. douronensis from Sarawak with $H$. dispar and $N$. stracheyi as outgroups. Bootstrap values are indicated above branch corresponding to MP, NJ and ML, respectively. Tree length is 341 with consistency index $(\mathrm{CI})=0.9724$ and retention index $(\mathrm{RI})=0.8601$. 


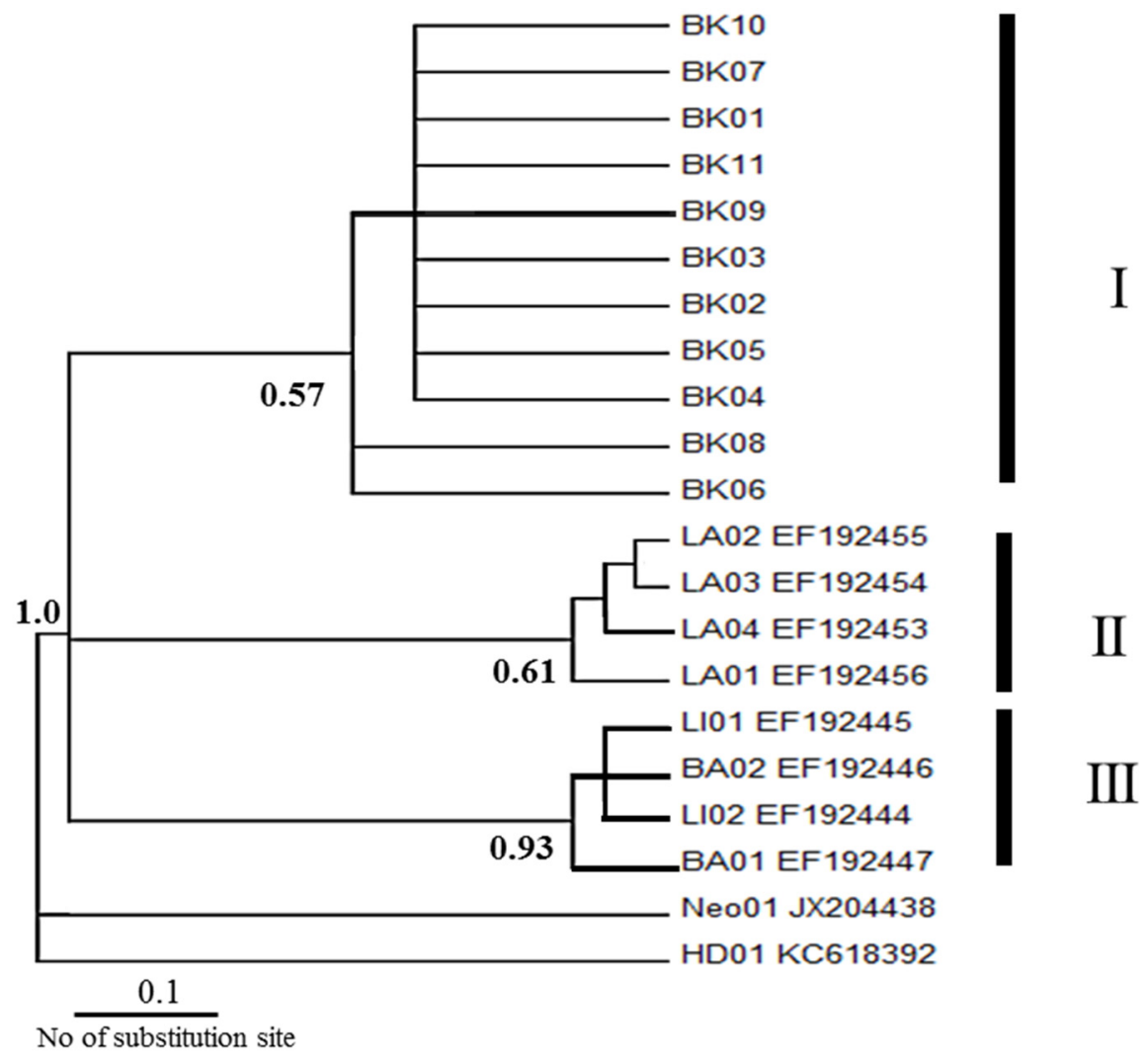

Figure 3. Bayesian inference of the $50 \%$ majority rule consensus tree of $\mathrm{CO} 1$ gene sequences of $T$. douronensis with $H$. dispar and $N$. stracheyi as outgroup.

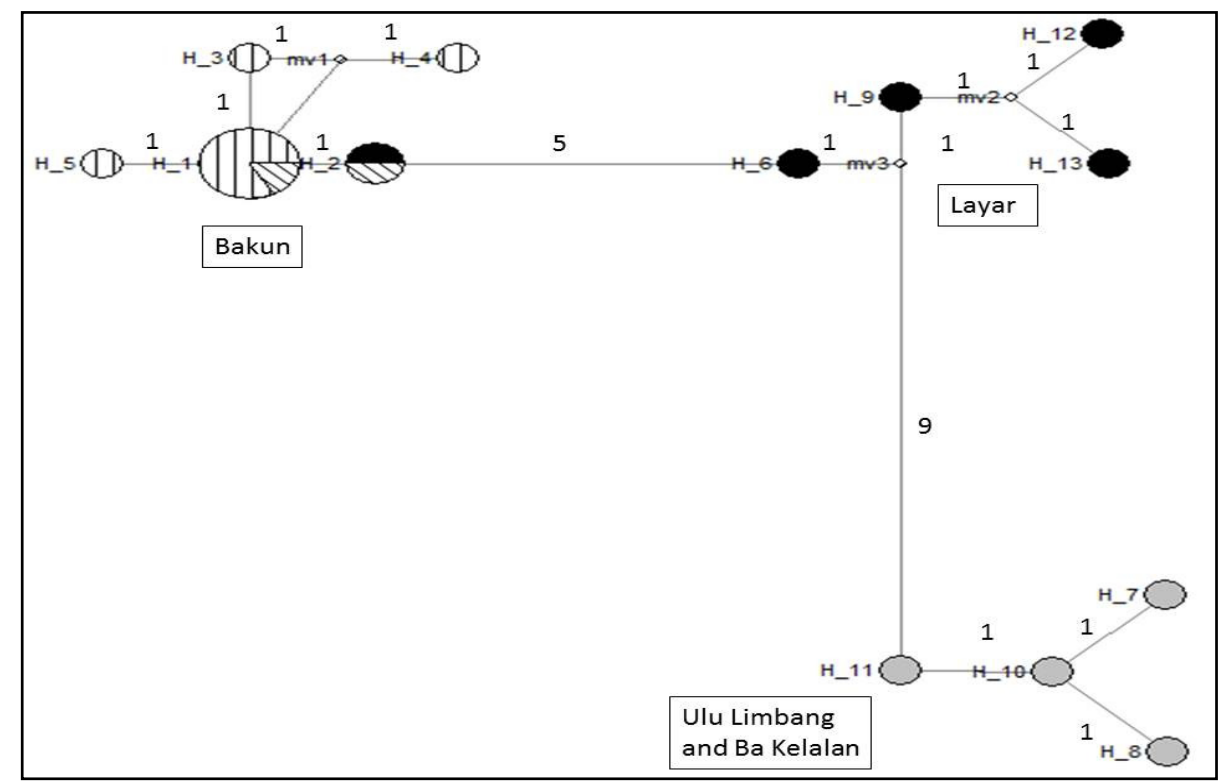

Figure 4. The minimum-spanning network (MSN) generated by Network 4.5.0.2 illustrating the relationships of T. douronensis in Sarawak. Each circle represents a haplotype, and the diameter is scaled to the haplotype frequency. Note that diagonal circles indicate Bakun haplotypes, black circles indicate Layar haplotype, and dark gray indicates Ulu Limbang and Ba Kelalan haplotypes. Numbers on the lines connecting haplotypes indicate number of mutational steps. 


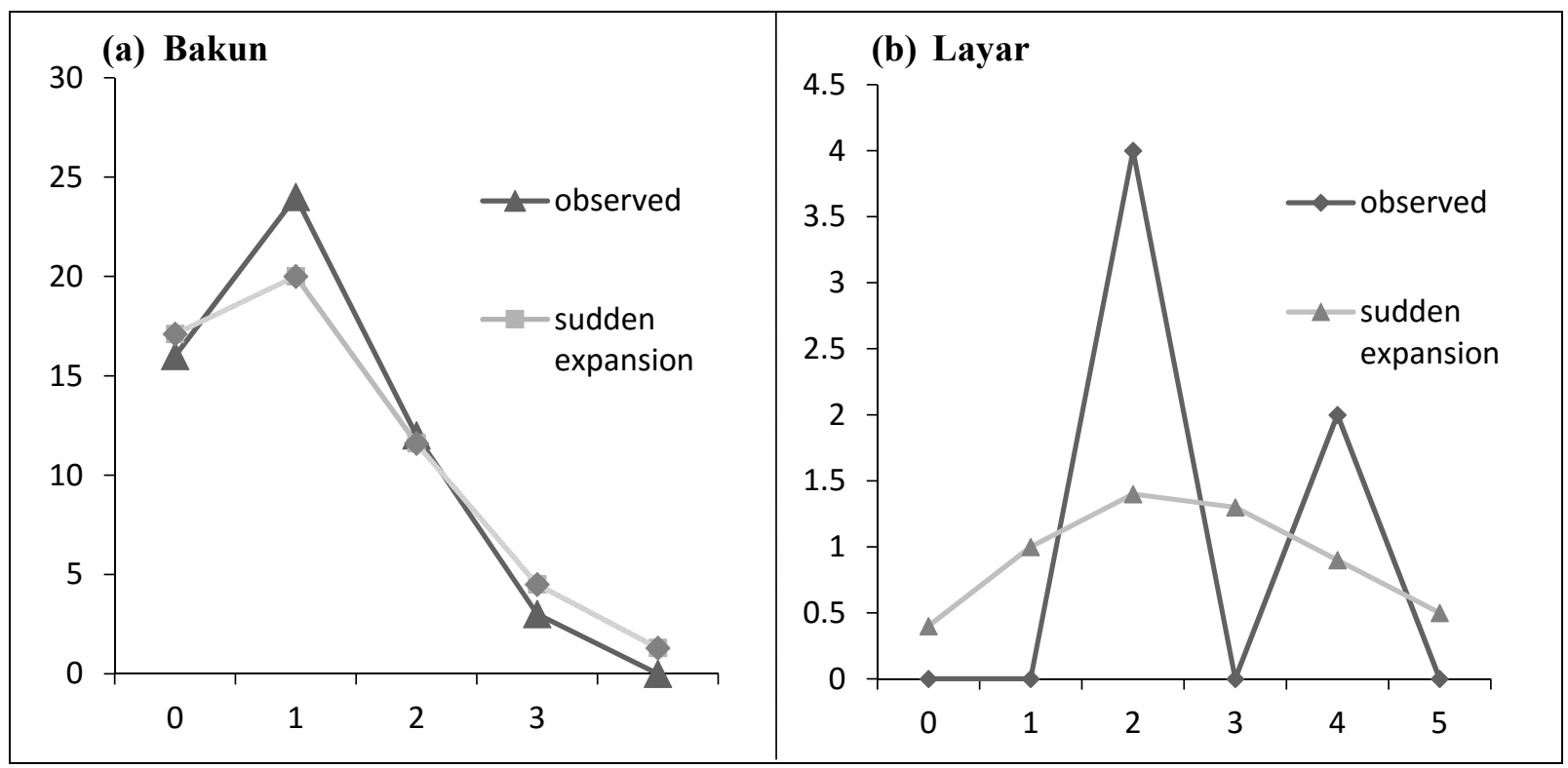

Figure 5. Mismatch distribution for (a) Bakun showing a unimodal distribution and (b) Layar showing multimodal distribution.

population ( $\mathrm{r}=1.111)$ with significant value $(\mathrm{p}=0.05)$ (Table 6), revealed multimodal interpretation of the mismatch distribution in $T$. douronensis. A unimodal distribution is indicative of population expansion whereas a multimodal distribution indicates constant population size over a long time period (Rogers \& Harpending, 1992).

To examine the demographic history and evolutionary neutrality of $T$. douronensis population, Tajima's test of neutrality (Tajima, 1989) and Fu's Fs statistical tests were conducted. Based on Table 7, the Tajima test was not significant with $\mathrm{p}$ more than 0.05 showing no deviation from evolutionary neutrality for all populations (Tajima, 1989). The scatterplot of the mismatch could not be generated for Ulu Limbang and Ba Kelalan populations might be due to no polymorphism was examined in the samples. The insignificant shown in $\mathrm{p}$ value from Ulu Limbang and $\mathrm{Ba}$ Kelalan $(\mathrm{p}=1.0)$ from Tajima's test (Table 5) also revealed that there had been no recent expansion occurring at Ulu Limbang and $\mathrm{Ba}$ Kelalan T. douronensis populations.

Moreover, the negative value of Fu's Fs statistics for Bakun population showed a negative (-1.20) and significant value (Table 6) indicating the presence of unique haplotype in the population (Zainudin et al., 2010) and inferring the population had undergone expansion or genetic hitchhiking (Fu, 1997).

AMOVA analysis (Table 7) shows high and significant differentiation (86.88\%) among $T$. douronensis populations in Sarawak. Furthermore, variation within population, although lower $(13.12 \%)$ is still significant, indicating presence of variation among individuals within a (or a few) population(s). This is likely contributed by Bakun and Layar populations as the pairwise divergence and nucleotide diversity of these two particular populations are high.

Genetic differentiation matrix was estimated to observe the genetic structure among $T$. douronensis populations in Sarawak. The estimated DST values among populations of $T$. douronensis showed significance except for the Ulu Limbang and Ba Kelalan (Table 8) populations suggesting closed relationship and potential high gene flow occurrence among these two populations while other pairwise population comparisons were low indicative of relatively low gene flow occurrence.

The high levels of nucleotide subdivision, $\mathrm{N}_{\mathrm{st}}$ and $\mathrm{F}_{\mathrm{ST}}$ value of 0.00 with high level of migrant per generation $(\mathrm{Nm}=-1.00$. $)$ between $\mathrm{Ba}$ Kelalan and Ulu Limbang populations (Table 9) suggesting that there is high gene flow between them. 
Table 6. Summary statistics of gene mtDNA sequence variation in four populations of $T$. douronensis in Sarawak.

\begin{tabular}{|c|c|c|c|c|c|c|}
\hline \multirow[t]{2}{*}{ Population } & \multirow[t]{2}{*}{$\mathrm{H}$} & \multirow[t]{2}{*}{$\% \operatorname{sdiv}$} & \multirow[t]{2}{*}{$\mathrm{D}$} & \multirow[t]{2}{*}{ Fs } & \multicolumn{2}{|c|}{ Sudden expansion } \\
\hline & & & & & SSD & $\mathrm{r}$ \\
\hline \multirow[t]{2}{*}{ Bakun } & 5 & $0.0-0.7$ & -0.88 & $-1.20^{* *}$ & 0.007 & 0.099 \\
\hline & & & $(\mathrm{p}=0.21)$ & $(\mathrm{p}=0.02)$ & $(p=0.652)$ & $(\mathrm{p}=0.626)$ \\
\hline \multirow[t]{2}{*}{ Layar/Spak } & 4 & $0.4-0.9$ & -0.21 & -1.41 & 0.297 & 1.111 \\
\hline & & & $(\mathrm{p}=0.55)$ & $(\mathrm{p}=0.06)$ & $(p=0.041)$ & $(p=0.052)$ \\
\hline \multirow[t]{2}{*}{ Ba Kelalan } & 2 & 0.4 & 0.0 & 0.69 & NA & NA \\
\hline & & & $(\mathrm{p}=1.00)$ & $(\mathrm{p}=0.35)$ & & \\
\hline \multirow[t]{2}{*}{ Ulu Limbang } & 2 & 0.2 & 0.0 & 0.0 & NA & NA \\
\hline & & & $(\mathrm{p}=1.00)$ & $(\mathrm{p}=0.26)$ & & \\
\hline
\end{tabular}

$\mathrm{H}=$ number of haplotypes, sdiv = pairwise sequence divergence (estimated using the HKY distance (Hasegawa et al., 1985), $\mathrm{D}=$ Tajima's statistic ( $\mathrm{P}(\mathrm{D}$ simul $<\mathrm{D}$ obs), (Tajima, 1989), $\mathrm{SSD}=$ sum of squared deviations of the observed and expected mismatch with $\mathrm{p}$ values in parentheses, $\mathrm{r}=$ raggedness statistic (Harpending, 1993 with $\mathrm{p}$ values in parentheses; $\mathrm{Fs}=\mathrm{Fu}$ 's statistic $(\mathrm{Fu}, 1997) .{ }^{* *}$ Significance $(\mathrm{p}<0.05)$ was determined using coalescent simulations in Excoffier (2005).

In contrast, Bakun and Limbang populations were the most differentiated and slightly isolated $\left(\mathrm{N}_{\mathrm{ST}}\right.$ or $\left.\mathrm{F}_{\mathrm{ST}}>0.9\right)$ with low gene flow $(\mathrm{Nm}=0.04)$ to (Table 9). The Bakun with $\mathrm{Ba}$ Kelalan and Ba Kelalan with Layar population pairwise are $\left(\mathrm{N}_{\mathrm{ST}}=0.89, \mathrm{~F}_{\mathrm{ST}}=0.89, \mathrm{Nm}=0.06\right)$ and $\quad\left(\mathrm{N}_{\mathrm{ST}}=0.79, \quad \mathrm{~F}_{\mathrm{ST}}=0.79, \quad \mathrm{Nm}=0.14\right)$ respectively. The result also revealed that $T$. douronensis population from Layar with Ulu Limbang was closer $\left(\mathrm{N}_{\mathrm{ST}}=0.84, \mathrm{~F}_{\mathrm{ST}}=0.84\right.$, $\mathrm{Nm}=0.09$ ) compare to Bakun with Limbang population although the distance between relationships of the four popualations $T$. LayarLimbang is $540 \mathrm{~km}$ while Bakun- Limbang is only $280 \mathrm{~km}$. Thus, the genetic douronensis are less likely related to geographical distance. But it is not fully resolved since the significance value cannot be generated due to low samples size.

Zainudin et al. (2010) reported that geographical barrier can also be an important factor for the high genetic divergence. The existence of large river, vast land area and isolated river reflect the species dispersal. This could also account for the observations in this study as evident by the AMOVA. Specifically, migration was hindered by geographical barrier except during the last Tertiary and Quaternary historical periods (Inger \& Chin, 2002) where the southern and northern part of Sarawak river system and channel were interconnected.

\section{CONCLUSION AND RECOMMENDATION}

A total of $465 \mathrm{bp}$ of the $\mathrm{CO} 1$ gene was successfully amplified from four populations of $T$. douronensis in Sarawak river systems revealing high genetic divergence values among populations. Three population subdivisions were observed representing central, southern, and northern population; $1^{\text {st }}$ clade (haplogroup I) from Bakun, $2^{\text {nd }}$ clade (haplogroup II) from Layar and $3^{\text {rd }}$ clade (haplogroup III) from $\mathrm{Ba}$ Kelalan and Ulu 
Table 7. Measures of geographical population differentiation in $T$. douronensis based on an analysis of molecular variance approach with cytochrome c oxidase subunit 1 data.

\begin{tabular}{|c|c|c|c|c|}
\hline Source of variation & $\begin{array}{c}\text { Variance } \\
\text { component }\end{array}$ & $\begin{array}{c}\text { Percent (\%) } \\
\text { variation }\end{array}$ & $\begin{array}{c}\text { Fixation index, } \\
\Phi\end{array}$ & $p^{\mathrm{a}}$ \\
\hline $\begin{array}{c}\text { Among } \\
\text { populations }\end{array}$ & 4.72 & 86.88 & 0.87 & $0.00 \pm 0.00^{*}$ \\
\hline Within populations & 0.71 & 13.12 & 0.87 & $0.00 \pm 0.00^{*}$ \\
\hline
\end{tabular}

Table 8. Genetic differentiation matrix of populations calculated by $\Phi$ ST. $P$ values are shown in parenthesis (below the diagonal).

\begin{tabular}{|c|c|c|c|c|}
\hline & Bakun & Layar & Limbang & Ba Kelalan \\
\hline Bakun & - & & & \\
\hline Layar & $0.83(0.00 \pm 0.00)^{*}$ & - & & \\
\hline Limbang & $0.92(0.00 \pm 0.00)^{*}$ & $0.81(0.00 \pm 0.00)^{*}$ & - & \\
\hline Ba Kelalan & $0.92(0.01 \pm 0.00)^{*}$ & $0.81(0.08 \pm 0.01)$ & $0.00(0.00 \pm 0.00)^{*}$ & - \\
\hline
\end{tabular}

*Significant $(\mathrm{p}<0.05)$ with 1000 permutations.

Table 9. Measures of nucleotide subdivision $\left(\mathrm{N}_{\mathrm{ST}}\right)$, population subdivision $\left(\mathrm{F}_{\mathrm{ST}}\right)$, and gene flow (number of migrants, $\mathrm{Nm}$ ) among 4 populations of T. douronensis.

\begin{tabular}{|c|c|c|c|c|}
\hline Locality & $\begin{array}{l}\text { Distance } \\
(\mathrm{km})\end{array}$ & $\begin{array}{c}\text { Nucleotide } \\
\text { subdivision }\left(\mathrm{N}_{\mathrm{ST}}\right)^{\mathrm{a}}\end{array}$ & $\begin{array}{c}\text { Estimate of } \\
\text { population } \\
\text { subdivision }\left(\mathrm{F}_{\mathrm{ST}}\right)^{\mathrm{b}}\end{array}$ & $\begin{array}{c}\text { Number of } \\
\text { migrant per } \\
\text { generation }\left(\mathrm{N}_{\mathrm{m}}\right)^{\mathrm{b}}\end{array}$ \\
\hline Bakun-Layar & 248 & 0.79 & 0.79 & 0.14 \\
\hline Bakun- Limbang & 280 & 0.92 & 0.92 & 0.04 \\
\hline Bakun-Ba kelalan & 215 & 0.89 & 0.89 & 0.06 \\
\hline Layar-Limbang & 540 & 0.84 & 0.84 & 0.09 \\
\hline Layar-Ba kelalan & 470 & 0.82 & 0.82 & 0.11 \\
\hline
\end{tabular}

${ }^{\mathrm{a}}$ Estimated using Lynch \& Crease (1990). ${ }^{\mathrm{b}}$ Estimated using Hudson et al. (1992). 
Limbang. Overall, there were 13 haplotypes and none was shared among populations, suggesting low level of inter-population gene flow has been observed. The small number of migrants per generation $(\mathrm{Nm}<1.0)$ among the population indicated that the small populations were separated, possibly by large geographical areas. All population had undergone expansion. Furthermore a large negative value and significant test of Fu' $\mathrm{Fs}$ in Bakun population suggested recent expansion. The result also suggested that all the populations do not deviate from evolutionary neutrality. Future studies should involve increased number and size of the populations in order to have a greater understanding of the genetic structure of $T$. douronensis in Sarawak.

\section{ACKNOWLEDGEMENTS}

Authors would like to thank UNIMAS for the field trip, chemicals and consumable, laboratory facilities and transportation. Special thank you to Prof Dr Lee Nyanti FRST UNIMAS for organizing field trip to Bakun Dam and useful discussions on the morphological aspects of Tor spp.

\section{REFERENCES}

Alexandrino, J, Jarntzen, J.W., \& Ferrand, N. (2002). Nested clade analysis \& the genetic evidence for population expansion in the phylogeography of the golden-striped salamander, Chioglossa lusitanica (Amphibia: Urodela). Heredity, 88: 66-74.

Bandelt, H.J., Forster, P., \& Röhl, A. (1999). Median-joining networks for inferring intraspecific phylogenies. Molecular Biology and Evolution, 16: 37-48.

Briolay, J., Galtier, N., Brito, R.M., \& Bouvet, Y. (1998). Molecular phylogeny of Cyprinidae inferred from cytochrome $b$ DNA sequences. Molecular Phylogenetic Evolution, 9(1): 100-108.

Donnelly, M.J., Licht, M.C., \& Lehmann, T. (2001). Evidence for recent population expansion in the evolutionary history of the malaria vectors Anopheles arabiensis and Anopheles gambiae. Molecular Biology and Evolution, 18: 1353-1364.
Doyle, J.J., L. \& Dickson, E.E. (1987). Preservation of plant samples for DNA restriction endonuclease analysis. Taxon, 36: 715-722.

Esa, Y.B., Siraj SS, Daud, S.K. Rahim, K.A.A. Abdullah, M.T., Japning, J.R.R., \& Tan, S.G. (2006). Mitochondrial DNA diversity of Tor douronensis Valenciennes (Cyprinidae) in Malaysian Borneo. Pertanika Journal of Tropical Agriculture Science, 29: 47-55.

Esa, Y.B., Siraj, S.S., Daud, S.K., Khairul Adha, A.R., Ryan, J.R.J., \& Tan, S.G. (2008). Mitochondrial DNA diversity of Tor tambroides Valenciennes (Cyprinidae) from five natural populations. Malaysian Zoology Study, 47(3): 360-367.

Excoffier, L. (2004). Patterns of DNA sequence diversity and genetic structure after a range expansion: lessons from the infinite-island model. Molecular Ecology, 13(4): 853-864.

Excoffier, L., Laval, G., \& Schneider, S. (2005). Arlequin vers. 3.0: an integrated software package for population genetics data analysis. Evolution Bioinformation Online, 1: 4750 .

Fu, Y.X. (1997). Statistical tests of neutrality of mutations against population growth, hitchhiking and background selection. Genetics, 147: 915-925.

Harpending, H.C., Sherry, S.T., Rogers, A.R., \& Stoneking, M. (1993). The genetic structure of ancient human populations. Current Anthropology, 483-496.

Hasegawa, M., Kishino, H., \& Yano, T. (1985). Dating the human-ape split by a molecular clock of mitochondrial DNA. Journal of Molecular Evolution, 22: 160-174.

Hudson, R.R., Boos, D.D., \& Kaplan, N.L. (1992). A statistical test for detecting geographic subdivision. Molecular biology and Evolution, 9(1): 138-151.

Huelsenbeck, J.P. \& Hillis, J.E. (1993). Success of phylogenetic methods in the four taxon case. Systematic Biology, 42: 247-264. 
Huelsenbeck, J.P. \& Ronquist, F.R. (2001). MrBayes: Bayesian inference of phylogenetic trees. Bioinformatics, 17: 754-755.

Inger, F.R. \& Chin, P.K. (2002). The freshwater fishes of North Borneo. Kota Kinabalu: Natural History Publication (Borneo).

Ingram, B.A., Sungan, S., Gooley, G.J., Sim, Y.S., Tinggi, D., \& De Silva, S.S. (2005). Induced spawning, larval development and rearing of two indigenous Malaysian Mahseer, Tor tambroides and Tor douronensis. Aquaculture research, 36: 1001-1014.

Kottelat, M., Whitten, A.J., Kartikasari, S.N., \& Wirjoatmodjo, S. (1993). Freshwater fishes of Western Indonesia and Sulawesi. Singapore: Periplus Edition.

Kumar, S., Dudley, J., Nei, M., \& Tamura, K. (2008). MEGA: a biologist-centric software for evolutionary analysis of DNA and protein sequences. Briefing in Bioinformatics, 9: 299-306.

Leache, A.D. \& Reeder, T.W. (2002). Molecular systematics of the eastern fence lizard (Sceloporus undulatus): a comparison of parsimony, likelihood, and Bayesian approaches. Systematic Biology, 51: 44-68.

Litis, B.A., Sungan, S., Jugang, K., Ibrahim, M., \& Bin, H.A. (1997). Features of indigenous fish species having potential for aquaculture. Sarawak: Inland Fisheries Division, Department of Agriculture.

Lynch, M. \& Crease, T.J. (1990). The analysis of population survey data on DNA sequence variation. Molecular Biology and Evolution, 7(4): 377-394.

Matsui M., Shimada, T., Ota, H., \& TanakaUeno, T. (2005). Multiple invasions of the Ryukyu Archipelago by Oriental frogs of the subgenus Odorrana with phylogenetic reassessment of the related subgenera of the genus Rana. Molecular Phylogenetic Evolution, 37: 733-742.
Mohsin, A.K.M. \& Ambak, M.A. (1983). Freshwater fishes of Peninsular Malaysia. Serdang: Universiti Pertanian Malaysia Publication.

Nei, M. (1987). Molecular evolutionary genetics. New York: Columbia University Press.

$\mathrm{Ng}$, C.K. (2004). Kings of the Rivers: Mahseer in Malaysia and the Region. Kuala Lumpur: Inter Sea Fishery.

Nguyen, T.T.T., Ingram, B., Sungan, S., Gooley, G., Sim, S.Y., Tinggi, D., \& De Silva, S.S. (2006). Mitochondrial diversity of broodstock of two indigenous mahseer species, Tor tambroides and Tor douronensis (Cyprinidae) cultured in Sarawak. Aquaculture, 253: 259-269.

Nyanti, L., Yee, L.T., \& Adha, K. (1999). Freshwater fishes from Bario, Kelabit Highlands. Asean review in biodiversity and environmental conservation. Pp 1-6.

Palumbi, S., Martin, A., Romano, S., McMillan, W.O., Stice, L., \& Grabowski, G. (1991). The simple fool's guide to PCR. Hawaii: Department of Zoology \& Kewalo Marine Laboratory, University of Hawaii.

Posada, D. (2008). jModelTest: phylogenetic model averaging. molecular biology and evolution. Molecular Biology and Evolution, 25: 1253-1256.

Rainboth, W.J. (1996). Fishes of the Cambodia, Mekong. FAD species identification field guide for fishery purposes. Rome: Food and Agriculture Organization

(FAO) Publication.

Rannala, B. \& Yang, Z. (1996). Probability distribution of molecular evolution trees: a new method of phylogenetic inference. Journal of Molecular Evolution, 43: 304311.

Roberts, T.R. (1989). The freshwater fishes of Western Borneo (Kalimantan Barat, Indonesia). California: California Academy of Sciences. 
Rogers, A.R. (1995). Genetic evidence for a Pleistocene population explosion. Evolution, 49: 608-615.

Rogers, A.R. \& Harpending, H. (1992). Population growth makes waves in the distribution of pairwise genetic differences. Molecular Biology and Evolution, 9: 552569.

Rozas, J., Sanches-DelBarrio, J.C., Messeguer, X., \& Rozas, S. (2003). DNASP, DNA polymorphism by the coalescent \& other methods. Bioinformatics, 19: 2496-3497.

Swofford, D.L. (2000). PAUP*. Phylogenetic Analysis Using Parsimony $(* \&$ other methods). Vers. 4.0b10. Sunderland, MA: Sinauer Associates.

Tajima, F. (1989). Statistical method for testing the neutral mutation hypothesis by DNA polymorphism. Genetics, 123: 585-595.
Thompson, J.D., Gibson, T.J., Plewniak, F., Jeanmougin, F., \& Higgins, D.G. (1997). The ClustalX windows interface: flexible strategies for multiple sequence alignment aided by quality analysis tools. Nucleic Acids Research, 24: 4876-4882.

Ray, N., Currat, M., \& Excoffier, L. (2003). Intra-deme molecular diversity in spatially expanding populations. Molecular Biology and Evolution, 20(1): 76-86.

Slatkin, M. \& Hudson, R.R. (1991). Pairwise comparisons of mitochondrial DNA sequences in stable and exponentially growing populations. Genetics, 129(2): $555-562$.

Zainudin, R., Nor, S.M., Ahmad, N., Md-Zain, B.M., \& Rahman, M.A. (2010). Genetic structure of Hyalarana erythraea (Amphibia: Anura: Ranidae) from Malaysia. Zoological Studies, 49(5): 688702 . 